\title{
VEGETATION STRUCTURE AND HEAVY METAL UPTAKE BY PLANTS IN THE MINING-IMPACTED AND NON MINING-IMPACTED SITES OF SOUTHERN LAKE VICTORIA WETLANDS
}

\author{
GYS Mtui ${ }^{1}$, C Mligo ${ }^{1}$, MKD Mutakyahwa ${ }^{2}$ and J.R. Ikingura ${ }^{2}$ \\ ${ }^{1}$ Department of Botany, University of Dar es Salaam, P O Box 35060, Dar es Salaam, Tanzania. \\ ${ }^{2}$ Department of Geology, University of Dar es Salaam, P O Box 35052, Dar es Salaam, Tanzania.
}

\begin{abstract}
This study assessed the plant species composition and the heavy metal uptake by plants in the mining-impacted and non mining-impacted areas of the southern Lake Victoria basin. The vegetation of the wetlands was stratified into riverine forest, riverine thickets, swampy grassland, open woodland and floodplain grassland. Plant diversity at Nyamtukuza ranged between 2.34 to 2.70; at Geita was 2.29 to 2.57 and Mwakitolyo was between 1.08 to 1.70 , which was significantly lower than the other two sites; whereas variation in plant species richness was not significant. TWINSPAN classification resulted into four clusters of the vegetation communities. Cluster A, a shrubby community with Combretum molle, Bersama abyssinica, Acalypha ornata and Acacia brevispica indicated previous cutting of woody species from the area. Cluster $B$ was a severely disturbed community with Bidens pilosa and Anthocleista grandiflora as early successors. Cluster $C$ was a community with moderate disturbance levels and cluster D was of wetland vegetation community types with indicator species such as Pistia stratiotes and Corchorus aestuans that are characteristic permanent wetland species. CCA ordination showed a significant positive correlation of the soil mineral elements to those in plants at axis 1. The influence of soil minerals on plant species distribution pattern was not significant at axis 1 .
\end{abstract}

\section{INTRODUCTION}

Lake Victoria is the second largest freshwater lake in the world covering a surface area of $68,000 \mathrm{~km}^{2}$. It is distributed among Tanzania (52\%), Uganda (42\%) and Kenya $(6 \%)$. The catchment area of $\mathrm{L}$. Victoria basin which also includes Rwanda and Burundi is one of the densely populated parts of Africa, with annual growth rate of 34\% (Ohwayo et al. 1997, Ikingura 2003). The biodiversity in the catchment areas of Tanzania's freshwater lakes is being devastated because of the increased population and associated increase in human activities such as mining, fishing, industries and agriculture (Mtui and Nakamura 2006).

The L. Victoria goldfields (LVGF) have the largest concentration of mining activities in the East African Region. Most of the lake catchment in Tanzania is heavily affected by mining operations, which are potential sources of toxic heavy metals (e.g. As, Pb,
$\mathrm{Cu}, \mathrm{Cd}, \mathrm{Cr}, \mathrm{Hg}$ ) through acid mine drainage and leaching of mine tailings. In addition, mercury released from artisanal gold mining operations in the LVGF is of environmental and human health concern, since its methylation in the wetlands could accelerate the entry of highly toxic methylmercury into aquatic food chain and bioaccumulation of mercury in fish resources (Ikingura and Akagi 1996, Ikingura 2003).

Small-scale gold mining (SSM) provides self-employment and means of life sustenance to over 300,000 people in the region. However, the mining has been largely semi-formal and sporadic, and hence difficult to regulate. Large-scale gold mining operations launched in 1980s around the LVGF are likely to exacerbate the effects of environmental degradation and heavy metal inputs into the lake catchments and eventually into the wetlands. The effects and extent of these mining operations and other 
human activities on the L. Victoria wetlands have not been investigated and evaluated.

The recommendations on management of $\mathrm{L}$. Victoria resources for sustainable development in the Great Lakes Region will depend on better understanding of natural and human activities and the processes operating within the lake environment. Activities that negatively affect the proper functioning of the lake ecosystem need to be identified carefully, studied and properly managed in order to preserve a delicate balance between the lake fauna and flora and human activities. Mining and other industrial activities are potential sources for toxic metals and other chemical pollutants into the lake environment, and are therefore worth studying for their chemical and biological effects on the wetlands (Greger 1999, Machiwa et al. 2004). The current interdisciplinary study assessed the vegetation dynamics in terms of composition, minerals in the soil and mineral uptake by plants in the South Lake Victoria wetlands.

\section{MATERIALS AND METHODS \\ Study sites}

The research study was carried out in the South Lake Victoria wetlands namely Mwakitolyo-Isanga channel (MW 1-7); Nyamutukuza-Bulyankhulu, (NY 1-8); Geita-Nungwe Bay (GT 1-14); Bukombe, (BU 1-4); Bulyankhulu (BU 1-7) and Sengerema (SE1-6). The last three sampling units are not impacted by mining operations and therefore served as control areas (Fig. 1).

\section{Sampling}

Fieldwork was done between January-June 2004. Soil/sediment and vegetation were sampled at specific locations in the study area (Fig. 1). Coordinates of the sampling points were determined and recorded using the GPS for reference purposes and subsequent follow up.

\section{Soil/sediment sampling}

Sampling was done in the floodplain by means of a corer of $10 \mathrm{~cm}$ in length and 3 $\mathrm{cm}$ diameter. Three samples were taken at a distance of $100 \mathrm{~m}$ apart from each sampling point. Each core sample was divided into two equal portions $(0-5 \mathrm{~cm}$ and $5-10 \mathrm{~cm})$ and placed in separate bags.

\section{Vegetation sampling}

Five transects of $1 \mathrm{~km}$ long were laid out in each habitat systematically at a distance of $100 \mathrm{~m}$ apart with the long axis of each transect cutting across the habitat under investigation. Within each transect, 10 nested quadrats were established and all plant species present identified. (a) (30 x 20) $\mathrm{m}^{2}$ quadrats for trees (b) $(5 \times 2) \mathrm{m}^{2}$ quadrats nested in the bigger quadrat for shrubs and saplings and (c) $(2 \times 0.5) \mathrm{m}^{2}$ quadrats nested in the $(5 \times 2) \mathrm{m}^{2}$ quadrats for herb layer, seedlings and grasses. The plants were identified to species level in the field whenever was possible and those which could not be identified were preserved fro identification using reference materials in the herbarium, at the Department of Botany, University of Dar es Salaam.

\section{Nutrient analysis from soils and sediments}

Samples of soil and sediments were dried in the oven at $105^{\circ} \mathrm{C}$ to constant weight. They were then ground and subjected to $0.2 \mathrm{~mm}$ diameter sieve. $0.5 \mathrm{~g}$ of sample was digested with $2 \mathrm{ml}$ aquaregia $\left(\mathrm{HCl} / \mathrm{HNO}_{3}\right.$ in the ratio of $3: 1$ in a marked test tube placed in a water bath at $100{ }^{\circ} \mathrm{C}$ for 15 minutes. The mixture was cooled and then diluted to 20 $\mathrm{ml}$. The clear solution was then analysed for heavy metals $(\mathrm{Cu}, \mathrm{Pb}, \mathrm{Zn}, \mathrm{Cd}, \mathrm{Co}, \mathrm{Ni}, \mathrm{Cr}$ and $\mathrm{Mn}$ ) by using a flame atomic absorption spectrophotometer (AAS) (Markert 2003). 


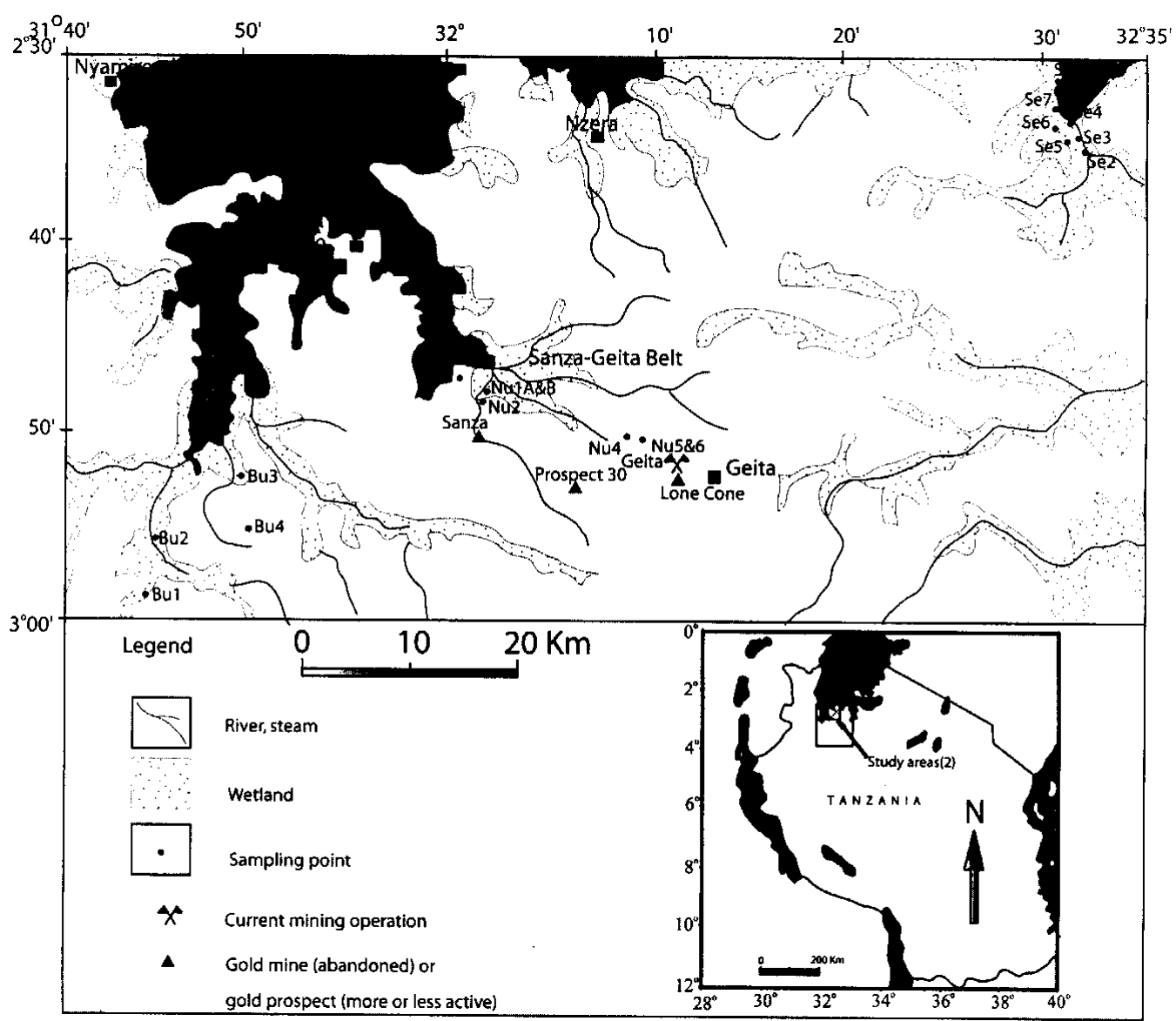

Figure 1: Location map showing the sampling sites in the study area.

\begin{abstract}
Analysis of heavy metals in the vegetation samples

Vegetation samples were air-dried and cooled in liquid nitrogen. They were then ground by using agate mortar and pestle to pass a mesh size of $0.5 \mathrm{~mm}$. One gram of powdered sample was accurately weighed and digested using concentrated nitric acid and then evaporated to near dryness, cooled and diluted to $50 \mathrm{ml}$. The solution was centrifuged and the supernatant was analyzed for metal content using flame AAS (Allen 1989, Markert 1994, 2003).
\end{abstract}

\section{Species Diversity Index}

Species diversity was determined by using Shannon and Wiener (1948) Diversity Index. The variation in species diversity was compared using two-way analysis of variance (ANOVA) (Zar 1996).

Two-Way Indicator Species analysis (TWINSPAN)

TWINSPAN was used in classifying the vegetation data according to Hill and Bunce (1975). It provided a means of allocating vegetation sample groups to the actual characteristics of the vegetation community types in terms of the influence of 
Mtui - Vegetation structure and heavy metal uptake ...

anthropogenic activities on the general vegetation characteristics.

\section{Vegetation ordination using Canonical Corresponding Analysis (CCA)}

CCA, a direct gradient ordination was used to assess how the environmental variables influence variation in vegetation distribution in the wetlands (ter Braak 1998). The vegetation habitat variable data matrices for canonical analyses were generated using Microsoft Excel spreadsheets and imported directly to CANOCO software through canoimport programme.

\section{RESULTS AND DISCUSSION}

Vegetation stratification and community classification

The common vegetation types in Mwakitolyo-Isanga Channel wetland were floodplain grassland, open woodland and cultivated crops such as maize (Zea mays); rice (Oryza sativa), cassava (Manihot esculentum), sweet potato (Ipomoea batatas), cowpea (Vigna sinensis) and tomato (Lycopersicon esculentum). The floodplain grassland was dominated by grass

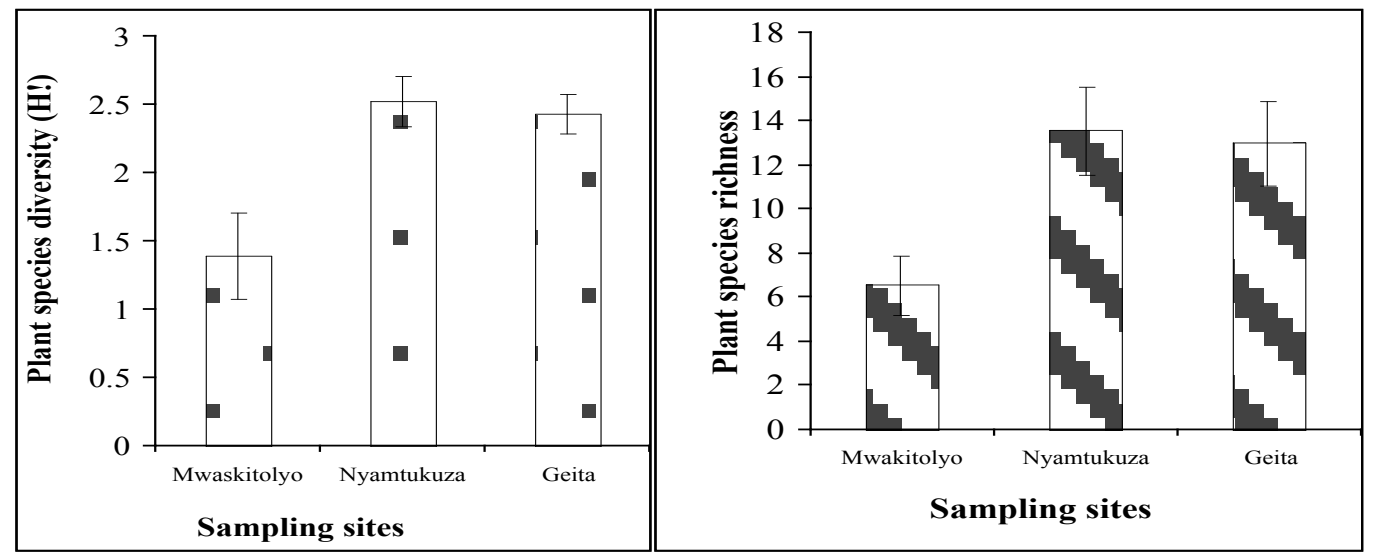

and sedges. Few hydrophytes such as Ludwigia sp, Polygonum senegalensis, Eichhornia crassipes, Typha capensis and Pistia stratiotes were common in waterlogged areas. This vegetation type was commonly used for animal grazing especially during the dry season. Also, most of the tree species in this vegetation type had been cut down for building poles and also as a source of firewood at the gold miner's camps. This resulted into the decrease in species richness of trees species compared to other sampling areas. Species diversity at Mwakitolyo ranged from 1.08 to 1.70 (Fig. 2), which was significantly lower than that from Geita and Nyamtukuza $(\mathrm{P}<$ $0.05)$, regardless of the homogeneity of the vegetation types. None of the extinctionthreatened species were found the in area. The low plant species diversity in this area is attributed to human activities that involve clearing of the vegetation for subsistence farming and mining (Ikingura 2003, Mtui and Nakamura 2006).

Figure 2: Variation in pant species richness and diversity of plant species in Mwakitolyo $(n=7)$, Nyamtukuza $(n=7)$ and Geita $(n=14)$ wetlands.

Nyamtukuza wetland is characterized by patches of swampy grassland vegetation with cultivated crops, mainly maize and few scattered rice fields. The common plant species in the area were grasses and sedges with few hydrophytes, shrubs and herbs. 
The upland areas and hilltops were intensively used for maize cultivation whereas the lowlands were used for paddy cultivation. Setaria sphacelata, Brachiaria eminii and Cyperus papyrus dominated the area forming a mat-like network in permanently water lodged areas. Species richness in this area ranged from 11.58 to 15.56 (Fig. 2). Species diversity at Nyamtukuza was 2.34 to 2.70 and was significantly higher than that of Mwakitolyo $(\mathrm{P}<0.05)$. High species diversity was probably due to the diverse nature of this habitat, which ranged from permanent water logged to semi arid areas.

Geita-Nungwe, Bukombe and Luchili Bay wetlands are characterized by riverine forest, riverine thickets, open woodland, floodplain grassland and subsistence crops including rice and maize that are extensively cultivated in the wetlands. Remarkably, Vanilla polylepis, a plant species with high socioeconomic value in food processing, glue and pharmaceutical industries (Ackerman 2003), was found growing at the riverine thickets in Bukombe area. However, the species is of high conservation significance since it falls under Appendices II and I of the Convention on International Trade in Endangered Species (CITES) of flora and fauna. Plant species richness in Geita was 11.07 to 14.92 and species diversity was 2.29 to 2.57 (Fig. 2) and was significantly higher than that of Mwakitolyo $(\mathrm{P}<0.05)$.

Although the Geita wetlands were the most impacted area as a result of mining and agricultural activities, they had higher plant species diversity than other areas. This could have been contributed by the invasion alien plant species or sprouting of rare species that suffered a long period of dominance. As a result of clearing of tree (canopy) species by the artisanal miners and farmers, the dormant seeds of rare plants species may have received sufficient light to stimulate their germination thereby increasing diversity of the vegetation in such areas (Tilman and Pascala 1993, Mligo 2004).

\section{Classification of vegetation communities using TWINSPAN}

TWINSPAN results (Fig. 3) showed that the study areas have been disturbed because the types of plant species found were mainly herbaceous and shrubby vegetation. Study sites, NY6, GT3, GT4 and GT8 did not differ considerably from the rest as they clustered together as community A, probably due to high similarity in species composition that are affected by similar levels of environmental disturbances. The indicator species of this community were Combretum molle, Bersama abyssinica, Acalypha ornata and Acacia brevispica. Human activities involving cutting of woody species resulted to an open vegetation with shrubs scattered all over the wetlands. Geita and Sengerema had similar species composition in which the vegetation type was classified as a community cluster $B$ where Bidens pilosa and Anthocleista grandiflora were the indicator species showing the vegetation clearance (Hyde and Wursten 2007). This implies that, the areas have suffered a high degree of disturbance either from mining activities, cultivation or other human activities. With the exception of NY6, all other plots from Nyamtukuza areas formed cluster $C$. The indicator species for the group is Mikamia cordata. Community Cluster $D$ consisted of only Mwakitolyo and that separated it from Nyamtukuza and Geita on the basis of Pistia stratiotes and Corchorus aestuans. The two indicator species are typical of disturbed wetlands with specific plant species distribution (Stone 1970) 


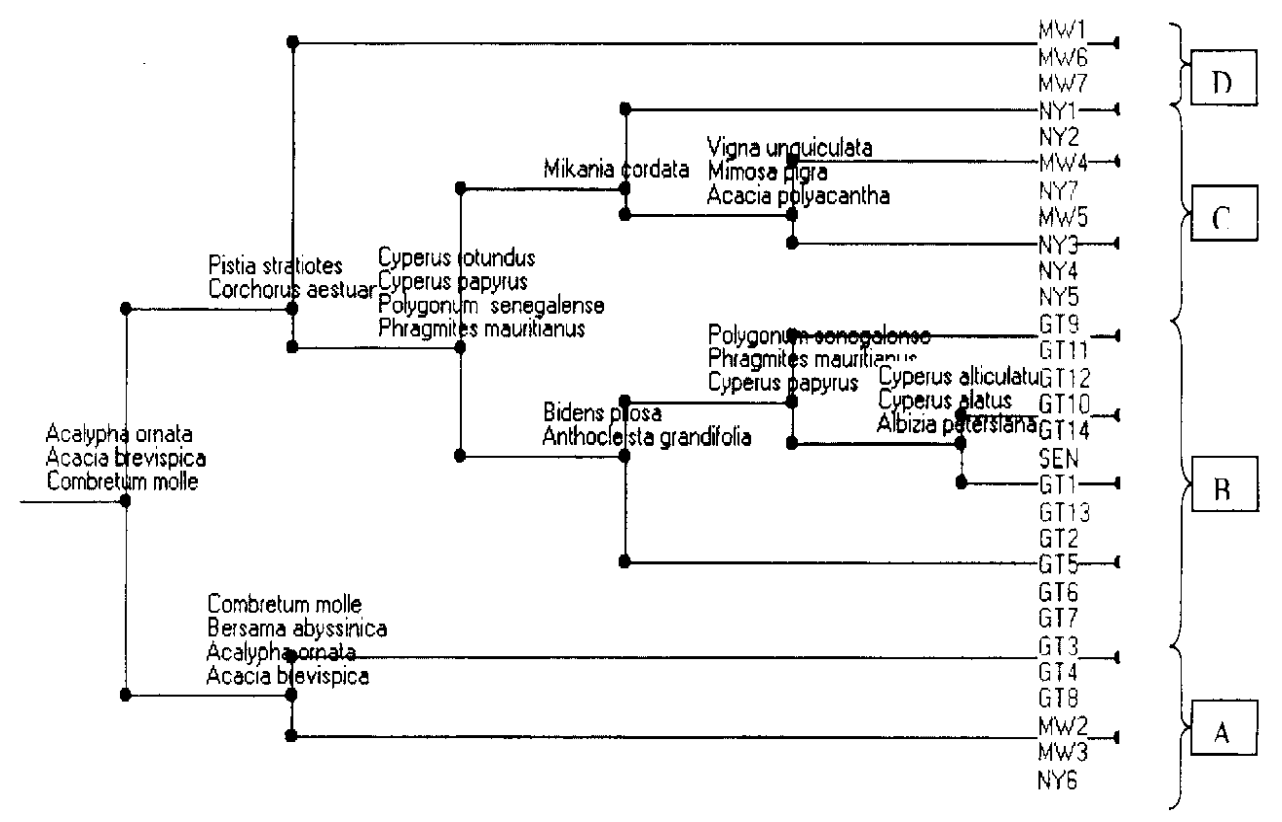

Figure3: TWINSPAN output showing clustering of vegetation samples in various communities.

\section{Heavy metal uptake in plants}

Table 1 summarizes heavy metal concentrations measured in plant tissues during the dry season. Chromium was below detection limit $(<0.01 \mathrm{mg} / \mathrm{kg})$ in all plant tissues analyzed. High values of copper concentration $(22-34 \mathrm{mg} / \mathrm{kg})$ was recorded in plants from Bulyankhulu and Nungwe-Geita wetlands, indicating more mobility and bioavailability of $\mathrm{Cu}$ for uptake by plants in those areas. $\mathrm{Pb}$ concentration varied from 0.1 to $20 \mathrm{mg} / \mathrm{kg}$ and the highest values were associated with plants from Bulyankhulu and Nungwe-Geita wetlands. $\mathrm{Zn}$ concentration ranged from 4 to $1,060 \mathrm{mg} / \mathrm{kg}$, highest concentrations were recorded in samples from Bulyankhulu and Nungwe-Geita wetlands. Cadmium concentration in the plant tissues ranged from $0.01-1.22 \mathrm{mg} / \mathrm{kg}$ in in Mwakitolyo, $0.01-1.16 \mathrm{mg} / \mathrm{kg}$ at Bulyankhulu, and $0.51-$ $2.22 \mathrm{mg} / \mathrm{kg}$ at Nungwe-Geita wetlands. The levels of heavy metals in plant samples from the control wetlands (Bukombe and Nzera) were relatively lower than the levels in mining-impacted Mwakitolyo-Isanga, Bulyankhulu, and Nungwe-Geita wetlands (Table 1).

The level of $\mathrm{Ni}$ ranged from 1 to $5 \mathrm{mg} / \mathrm{kg}$ in plant tissues analysed, with exception of a few samples from Bulyankhulu, which contained low Ni concentration $(0.5 \mathrm{mg} / \mathrm{kg})$. Cobalt concentration showed a wider range of variation than nickel $(0.4 \mathrm{mg}-47 \mathrm{mg} / \mathrm{Kg})$ in the plant tissues. Plants from Bulyankhulu and Nungwe-Geita wetlands recorded 15-47 $\mathrm{mg} / \mathrm{kg}$ of Co and these areas were highly affected by mining operations compared to the rest of the wetlands covered in the present study. These values were higher than those from the control areas, showing the effects of mining operations on the wetland ecosystems.

Abnormally high concentration of manganese were recorded from plant samples in all wetlands regardless of the influence of mining operations (Table 1). It appears that, the bioavailability of $\mathrm{Mn}$ for uptake by 
plants was quite high in all wetlands covered by the study. The maximum As concentration of plant materials sampled in mining-impacted sites was $2.44 \mathrm{mg} / \mathrm{kg}$.
This concentration was high compared to $1.12 \mathrm{mg} / \mathrm{kg}$ in Bukombe and Nzera control sites.

Table 1: Heavy metal levels (mg/kg, d.w.) in plants from wetlands of South Lake Victoria during the dry season.

\begin{tabular}{|c|c|c|c|c|c|c|c|c|c|}
\hline & $\mathbf{C u}$ & $\mathbf{P b}$ & $\mathbf{Z n}$ & $\mathbf{C d}$ & $\mathrm{Cr}$ & $\mathbf{N i}$ & Co & Mn & As \\
\hline $\begin{array}{l}\text { Mwakitolyo } \\
(\mathrm{N}=11)\end{array}$ & 4-14 & $1-13$ & $4-38$ & $\begin{array}{l}0.01- \\
1.22\end{array}$ & $<0.01$ & $1-5$ & $0.4-4$ & $5-281$ & $0.01-2.4$ \\
\hline $\begin{array}{l}\text { Bulyankhulu } \\
(\mathrm{N}=18)\end{array}$ & $4-34$ & $\begin{array}{l}0.1- \\
15\end{array}$ & $8-234$ & $\begin{array}{l}0.01- \\
1.16\end{array}$ & $<0.01$ & $0.5-4$ & $0.4-47$ & $10-11127$ & $\begin{array}{l}<0.01- \\
2.44\end{array}$ \\
\hline $\begin{array}{l}\text { Geita } \\
(\mathrm{N}=5)\end{array}$ & $4-22$ & $4-20$ & $\begin{array}{l}22- \\
1060\end{array}$ & $\begin{array}{l}0.51- \\
2.22\end{array}$ & $<0.01$ & $2-5$ & $2-15$ & 246-3009 & $0.5-1.4$ \\
\hline $\begin{array}{l}\text { Bukombe* } \\
(\mathrm{N}=1)\end{array}$ & 7 & 12 & 41 & 0.84 & $<0.01$ & 3 & 5 & 411 & 0.33 \\
\hline Nzera $*(\mathrm{~N}=1)$ & 3 & 9 & 27 & 1.08 & $<0.01$ & 3 & 13 & 3494 & 1.12 \\
\hline
\end{tabular}

*Control wetlands not impacted by gold mining

Table 2: $\quad$ Heavy metal levels $(\mathrm{mg} / \mathrm{kg})$ in plants from wetlands of South of Lake Victoria during the wet season.

\begin{tabular}{lllllllll}
\hline Locality & $\mathbf{C u}$ & $\mathrm{Pb}$ & $\mathbf{Z n}$ & $\mathbf{C d}$ & $\mathbf{C r}$ & $\mathbf{N i}$ & $\mathbf{C o}$ & $\mathbf{M n}$ \\
\hline Mwakitolyo & $0.01-7.3$ & $0.01-$ & $7.0-66.4$ & $0.001-$ & $0.48-1.63$ & $0.01-4.14$ & $0.01-0.88$ & $4.38-$ \\
$(\mathrm{N}=12)$ & & 3.5 & & 0.394 & & & & 54.16 \\
Bulyankhulu & $0.32-$ & $0.01-$ & $13.65-$ & $0.001-$ & $0.01-4.35$ & $0.01-4.76$ & $0.01-2.30$ & $9.20-$ \\
$(\mathrm{N}=8)$ & 31.57 & 2.02 & 47.91 & 0.271 & & & & 332 \\
Geita & $0.01-$ & $1.48-$ & $18.78-$ & $<0.001$ & $0.01-0.30$ & $0.01-0.93$ & $0.01-0.57$ & $30.81-$ \\
$(\mathrm{N}=2)$ & 0.40 & 1.56 & 25.20 & & & & & 40.48 \\
Bukombe* & $0.25-$ & $0.01-$ & $16.95-$ & $<0.001$ & $0.01-0.23$ & $0.01-0.75$ & $0.01-0.04$ & $13.70-$ \\
$(\mathrm{N}=4)$ & 1.87 & 1.20 & 24.50 & & & & & 58.49 \\
Sengerema* & $0.63-$ & $1.57-$ & $15.15-$ & $0.001-$ & $0.01-2.57$ & $0.01-2.69$ & $0.14-2.57$ & $8.49-$ \\
$(\mathrm{N}=6)$ & 3.74 & 4.60 & 27.55 & 0.557 & & & & 737 \\
\hline
\end{tabular}

*Control wetlands not impacted by gold mining, \# Values $<0.01$ and $<0.001$ are reported as 0.01 and 0.001 in all tables.

Table 2 shows heavy metal concentrations in plants during the wet season. $\mathrm{Cu}$ concentration ranged from $<0.01 \mathrm{mg} / \mathrm{kg}$ to $31.57 \mathrm{mg} / \mathrm{kg}$ and the highest value was found in a plant sample from Bulyankhulu. Highest concentrations of $\mathrm{Pb}$ and $\mathrm{Zn}$ recorded in Mwakitolyo wetland were 3.5 $\mathrm{mg} / \mathrm{kg}$ and $66.4 \mathrm{mg} / \mathrm{kg}$, respectively. Within the Bulyankhulu wetland, $\mathrm{Zn}$ content in plants ranged from $13.65 \mathrm{mg} / \mathrm{kg}$ to 47.91 $\mathrm{mg} / \mathrm{kg}$. Plants in Bukombe, Geita and Sengerema had $\mathrm{Zn}$ levels ranging from $15.15 \mathrm{mg} / \mathrm{kg}$ to $27.55 \mathrm{mg} / \mathrm{kg}$. Cd in plants ranged from $<0.001$ to $0.557 \mathrm{mg} / \mathrm{kg}$, in Sengerema and Mwakitolyo whereas those from Geita and Bukombe, were below the detection limit $(<0.001 \mathrm{mg} / \mathrm{kg})$. Cr, Ni and Co concentrations ranged between $<0.01$ to $4.76 \mathrm{mg} / \mathrm{kg}$ in Bulyankhulu plant samples. $\mathrm{Mn}$ range was from $9-332 \mathrm{mg} / \mathrm{kg}$ for Bulyankhulu samples and from 8 - 737 $\mathrm{mg} / \mathrm{kg}$ for Sengerema samples. However, it was low in Mwakitolyo-Isanga Channel wetland (4-54 mg/kg), Bukombe (14-58 $\mathrm{mg} / \mathrm{kg}$ ) and in Nungwe-Geita wetland (31-40 $\mathrm{mg} / \mathrm{kg}$ ). 
Heavy metals such as $\mathrm{Cu}, \mathrm{Cd}$ and $\mathrm{Pb}$ are known to alter the functions of photosynthesis in plants in different levels. For instance, the critical toxic $\mathrm{Cu}$ level in leaves of all plant species is about 20 to 30 $\mu \mathrm{g} / \mathrm{g}$ dry weight (Prasad and Hagemeyer 1999). It is obvious that the level of $\mathrm{Cu}$ in plant species from Bulyankhulu with up to $34 \mu \mathrm{g} / \mathrm{g}$ is alarming. Elongation of roots, stunted plants and malformed leaves have been observed in other parts of the world as a result of increased $\mathrm{Cu}$ levels (Förstner and Wittman 1979).
The relationships existing in some heavy metals in plants can be explained by the fact that, sometimes the combination of elements in plants lead to increase or decrease of certain effects (Prasad and Hagemeyer 1999). Uptake of heavy metals $(\mathrm{Cd}, \mathrm{Cu}, \mathrm{Fe}, \mathrm{Pb}, \mathrm{Mg}, \mathrm{Ni}$ and $\mathrm{Zn})$ in plants is promoted by low $\mathrm{pH}$ values and anaerobic conditions. Certain plant species may have elevated concentrations of heavy metals by virtue of being hyper-accumulators of particular element (Streit and Stumm 1993).

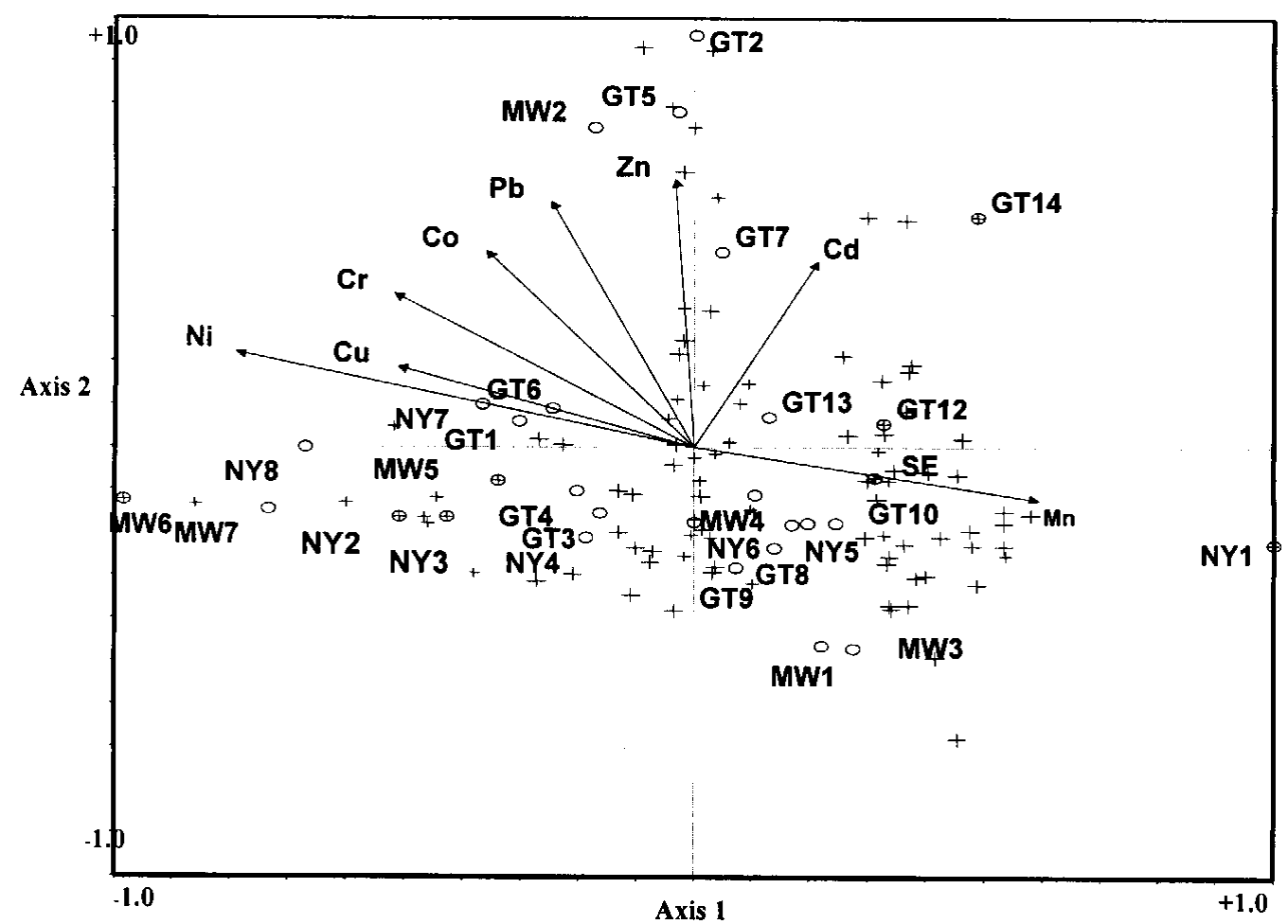

Figure 4: CCA triplot on the influence of soil mineral elements on vegetation distribution ( $o$ and $\oplus=$ sites; $+=$ species $)$.

Influence of soil mineral elements on plant species distribution patterns

The CCA ordination showed no clear pattern in the influence of mineral elements on samples of vegetation distribution (Fig. 4).
All the four CCA axes showed almost similar levels of the species variations. (Axis $1=0.538$, Axis $2=0.522$, Axis $3=$ 0.506 and Axis $4=0.448$ ). The Monte Carlo Permutation test showed no 
significant influence of the measured mineral elements on samples of plant species distribution in the wetlands $(\mathrm{F}=0.960$, $\mathrm{P}=0.86$ ). However, manganese influence was high on the first CCA axis compared to other nutrient elements for the Plots MW1, MW3, MW4, GT9/10/11 and NY1/5/6. This could be due to the fact that the soil in the area is characterized by high levels of manganese and the plant species are seemingly tolerant to such levels. On the other hand, MW5/6/7, NY2/3/4/8 and GT3/4 were moderately influenced by the concentration of almost all the mineral elements.

Relationships between soil mineral elements and minerals in the plants

The CCA ordination results showed a significant influence of concentration of soil elements and those in plant tissues $(\mathrm{F}=$ 34.920, $\mathrm{P}=0.025$ ) (Fig. 5). The CCA axis 1 indicated the highest percentage variation of soil and plant samples from different sampling sites $(27 \%)$. This is due to high concentration of $\mathrm{Mn}$ in the soil samples than it was in the plant materials. This was confirmed by an attempt to abandon $\mathrm{Mn}$ in CCA analysis where Monte Carlo Permutation test indicated no significant difference between them $(\mathrm{P}>0.05)$. There is a clear separation of plots analysed for mineral elements from the soil and those plots analysed for the same elements from plants. This indicates that there is a high positive correlation between the soil mineral elements to those in plant tissues $(\mathrm{r}=$ 0.998).

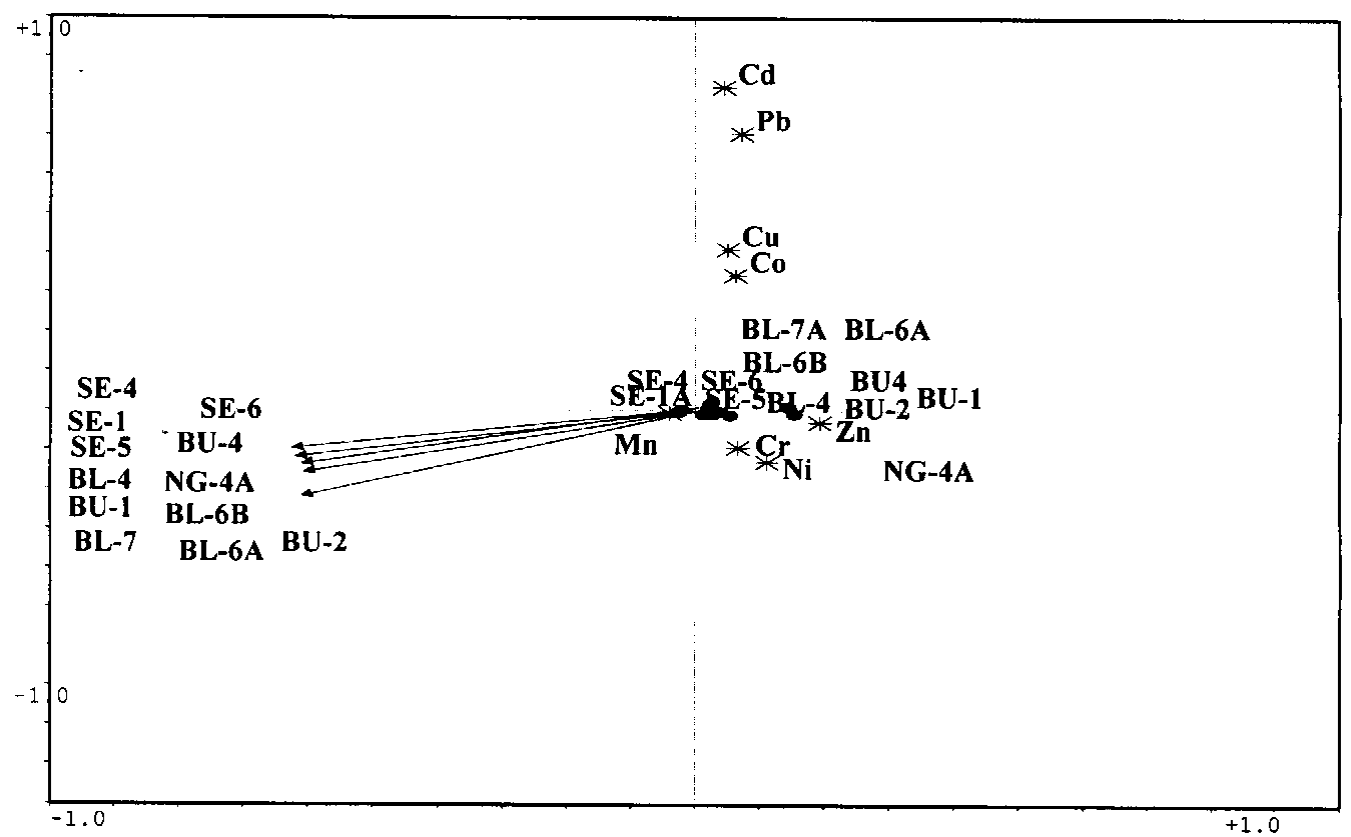

Figure 5: The correlation between the elements in the soil and that of the same elements in the plants using CCA ordination.

\section{CONCLUSIONS}

The study revealed that vegetation communities of areas that have been heavily impacted by mining and cultivation are either dominated by herbaceous species or shrubs. Also, increased concentration of 
heavy metals in the mining-impacted sites of the wetland soils was positively correlated with the bioaccumulation of such elements in plant tissues. The results of this study provide baseline data upon which more elaborate studies can be made. The findings of this work will be helpful to decision makers on proper management of the wetlands for socio-economic development of the people in the L. Victoria basin. It is recommended that human activities around Lake Victoria wetlands should go had in hand with environmental conservation measures. A detailed vegetation analysis including succession of plant species and invasive species in the wetlands should be the focus of future studies.

\section{ACKNOWLEDGEMENTS}

We would like express gratitude to the Sida/SAREC Project for financial support. Many thanks are due to the Secretariat of the Inter-University Council of East Africa (IUCEA) for logistical facilitation. The staff of the Departments of Botany and Geology, University of Dar es Salaam, and the Southern and Eastern African Mineral Centre (SEAMIC) are acknowledged for their $\mathrm{t}$ e $\mathrm{ch} \mathrm{n} \mathrm{c} \mathrm{a} \mathrm{s} \mathrm{u} \mathrm{p} \mathrm{p} \mathrm{o} \mathrm{r} \mathrm{t} \mathrm{.}$

\section{REFERENCES}

Ackerman, J. D 2003 Vanilla Miller, Flora N. Amer. 26:507.

Allen S E 1989 Chemical Analysis for Ecological Materials. $2^{\text {nd }}$ Ed. Blackwell.

Förstner U and Wittman GTW 1979 Metal pollution in the aquatic environment. Springer, Berlin.

Greger M. 1999 Metal Availability and Bioconcentration in Plants. In: Prasad, M.N.V. and Hagemeyer, J (Eds.) Heavy Metal Stress in Plants, Springer, Berlin. pp 1-27.

Hyde M and Wursten, B. 2007. Flora of imbabwe:

htpp://www.Zimbabweflora.co.zw Speciesdata/about.php

Hill MO, and Bunce GH 1975 Indicator Species Analysis. J. Ecol. 63: 597 614.
Ikingura JR $2003 \quad$ Environmental transformation of mercury from gold mining operations and implications on human health in Lake Victoria goldfields. Afr. Geosci. Rev. 9: 279-288.

Ikingura JR and Akagi H 1996 Monitoring of fish and human exposure to mercury due to gold mining in Lake Victoria goldfields, Tanzania. Sci. Total Environ. 191:59-68.

Kent M and Koker C 1995 Vegetation Description and Analysis. A Practical Approach. Belhaven Press, London.

Machiwa JF, Lugomela C and Muzuka A 2004 Phytoplankton and Nutrients Studies in Magu Bay, Speke Gulf, Lake Victoria, Tanzania. Tanz. J. Sci. 30: 3342.

Markert BA, Breure AM and Zechmeinster HG 2003 Bioindicators and Biomonitors. Principles, Concepts and Applications. 6. Elserver, London.

Markert BA 1994 Environmental Sampling for Trace Analysis. VCH Publishers, New York.

Mligo C 2004 Pasture Dynamics in the Semi-arid Mbulu District, Tanzania. MSc Thesis, University of Dar es Salaam.

Mtui GYS and Nakamura Y 2006 Physicochemical and Microbiological Water Quality of Lake Sagara in Malagarasi Wetlands. J. Eng. Appl. Sci. 1(2): 174-180

Ohwayo, R.O.; Hecky, R.E.; Cohen, A.S \& Kaufman, L. 1997 Human impacts on the African Great Lakes. Envir. Biol. Fish. 50: 117-131,

Prasad M N V and Hagemeyer J 1999 Heavy Metal Stress in Plants. Springer Verlag, Berlin.

Shannon, C. F. and Wiener, W. 1948. The mathematical theory of Communication. University of Illinois Press, Urbana.

Streit B and Stumm W 1993 Chemical Properties of Metals and the Process of Bioaccumulation in Terrestrial Plants. In Markert Bernd (eds): Plants as Biomonitors: Indicators for Heavy 
Metals in the Terrestrial Environment. VCH Cambridge.

Stone, B C. 1970. The flora of Guam. Microne. 6:1-659

Ter Braak C J F 1998 Reference Manual and User's guide to CANOCO for Windows. Ithaka.
Tilman D. and Pacala S 1993 The maintenance of Species richness in plant communities. In R.E., Ricklefs and Schluter D (Eds) Species Diversity in Ecological Communities. University of Chicago Press, Chicago, pp13-25.

Zar J H 1996 Biostatistical Analysis. Prentice-Hall, Inc. Englewood Cliff's. 